\title{
Extraskeletal Osteosarcoma: A Case Report
}

\section{Ekstraskeletal Osteosarkom: Olgu Sunumu}

\author{
Fisun Ardıç Yükrük ${ }^{1}$, Fatma Markoç ${ }^{1}$, Ayșe Şerife Salan Berkel ${ }^{2}$, Elife Aktaş ${ }^{3}$ \\ ${ }^{1}$ Dr. A. Y. Ankara Onkoloji Eğitim Ve Araştırma Hastanesi, Patoloji Kliniği, Ankara, Türkiye \\ ${ }^{2}$ Mersin Toros Devlet Hastanesi, Mersin, Türkiye \\ ${ }^{3}$ Adana Numune Eğitim Ve Araştırma Hastanesi, Patoloji Kliniği, Adana, Türkiye
}

DOI: $10.5505 /$ aot.2011.17363

\section{ÖZET}

Extraosseöz osteosarkom (ESOS), yumuşak dokunun osteoid, kemik ya da kondroid materyal üreten malign mezenkimal neoplazmı olarak tanımlanan nadir görülen tümörüdür. Tüm yumuşak doku sarkomlarının $\% 1.2$ 'sini, tüm osteosarkomların ise \%4'ünden azını oluşturur. Temel olarak retroperiton ve ekstremitelerin yumuşak dokusunda görülür ve kemik ya da periosteum ile ilişkisi yoktur. Kemiğin osteosarkomu ilk iki dekatta görülmesine karşın, ESOS 40 yaşın üzerindeki hastalarda görülür. Meme, deri, mesane, akciğer ve mediasten, dil, spermatik kord ve penis, cerebrum, kolon ESOS'un bildirilmiş olağandışı lokalizasyonlarıdır. Sunulan olguda histopatolojik olarak epiteloid ve iğsi hücrelerin arasında fokal olarak osteoid üretimi nedeniyle ESOS tanısı verilmiştir.

Anahtar Kelimeler: Osteosarkom; Ekstraosseöz

\section{ABSTRACT}

Extraskeletal osteosarcoma (ESOS) is a rare high-grade malign mesenchymal tumor of soft tissue that produce osteoid, bone and chondroid matrix. It accounts for $1.2 \%$ of all soft tissue sarcomas and less than $4 \%$ of all osteosarcomas. ESOS occurs basically in soft tissue of the extremities and retroperitoneum and has no attachment with the underlying bone or periosteum. In contrast to osteosarcoma of the bone, which is seen in the first two decades, ESOS most commonly occurs in patients older than 40 years. Breast, skin, bladder, lung and mediastinum, tongue, spermatic cord and penis, cerebrum and colon are other extraordinary localizations of ESOS. In presented case ESOS diagnosis was made due to focal osteoid production between epitheloid and spindle shaped cells.

Key words: Osteosarcoma; Extraskeletal

\section{Giriş}

Ekstraskeletal osteosarkom (ESOS), yumuşak dokunun osteoid, kemik ya da kondroid materyal üreten malign mezenkimal neoplazmı olarak tanımlanan nadir görülen tümörüdür. Tüm yumuşak doku sarkomlarının \%1.2'sini, tüm osteosarkomların ise \%4'ünden azını oluşturur (1-3). Tümör temel olarak retroperiton ve ekstremitelerin yumuşak dokusunda görülür ve kemik ya da periosteum ile ilişkisi yoktur. Kemiğin osteosarkomu ilk iki dekatta görülmesine karşın, ESOS, 40 yaşın üzerindeki hastalarda görülür. Meme, deri, mesane, akciğer, dil, spermatik kord, serebrum ve kolon ESOS'un bildirilmiş olağandışı lokalizasyonlarıdır (3-12). Histopatolojik olarak epiteloid ve iğsi hücrelerin arasında fokal olarak osteoid üretimi nedeniyle ESOS tanısı verilmiştir.

\section{Olgu Sunumu}

Doğuştan kalça çıkı̆̆ı olan 52 yaşında kadın hasta, 6 ay kadar önce başlayan sol gluteal bölgede şişlik şikayeti ile başvurduğu bir diş merkezde kitle tespit edilerek opere edilmiştir. Operasyon materyalinde $5.5 \times 4.5 \times 2 \mathrm{~cm}$ ölçülerinde tümör saptanarak 'yüksek dereceli leiomyosarkom' tanısı konulmuş. Hasta, bir ay içinde sol gluteal bölgedeki şişliğin tekrar büyümesi üzerine, hastanemiz genel cerrahi kliniğine başvurdu. Fizik muayenede eski operasyon bölgesinde kitle tespit edilerek geniş re-eksizyon uygulandi. Radyolojik görüntülemede ve operasyon sırasında kitlenin, kemik yapılarla ilişkisiz olduğu görüldü (Resim 1). Hastada doğumsal kalça çıkı̆̆ dişında lokal travma ya da radyasyona maruziyet öyküsü yoktu. Palpabl lenf nodu, BT'de akciğer ve karaciğerde metastazı düşündürecek bulgu izlenmedi. Laboratuar incelemesinde serum alkalen fosfataz seviyesi 
dahil tüm bulgular normal sınırlarda değerlendirildi.

Makroskopik olarak, eksize edilen spesmende $4 \times 2 \times 1 \mathrm{~cm}$ ölçülerinde kitle saptand1. Kesi yüzleri, nisbeten düzgün sınırlı, multinodüle görünümde, krem-beyaz renkli, yer yer sert kıvamlıydı. Nekroz ve hemoraji izlenmedi.

Mikroskopik olarak, deri altında, derin dermis ve subkutan yağ dokusunda lokalize, kas dokusunu da infiltre eden tümöral doku görüldü. Tümör kollajenize stromaya sahip fibroblastik ve 'lace-like' paternde osteoid üretiminin belirgin olduğu osteoblastik komponentten oluşmaktaydı (Resim 2). Fibroblastik komponent, yer yer birbirleriyle kesişen uzun demetler oluşturan iğsi bir kısmı oval-yuvarlak, yer yer oldukça pleomorfik, hiperkromatik nukleuslu, sınırları seçilemeyen eozinofilik sitoplazmalı, çok sayıda tipik ve atipikmitotik figür içeren atipik mezenkimal hücrelerdi. Osteoblastik komponenti, oldukça iri ve pleomorfik, hiperkromatik nukleuslu, düzensiz konturlu bizar hücreler, osteoklast tipi multinükleer dev hücreler ile epiteloid hücreler oluşturdu (Resim 3). Bu alanlarda tümör hücreleri tarafindan üretilen osteoidde yer yer mineralizasyon bulguları izlenirken (Resim 4), 'keçemsi kemik' benzeri osteoid üretimi de dikkati çekti (Resim 5). İmmunohistokimyasal (İHK) incelemelerde, aktin ve vimentin ile tümör hücrelerinde yaygın kuvvetli boyanma izlenirken, pansitokeratin, CD34, S-100 protein, desmin, p53, EMA ve bcl-2 ile boyanma görülmedi. Ki-67 ile proliferatif indeks \%30 olarak değerlendirildi.

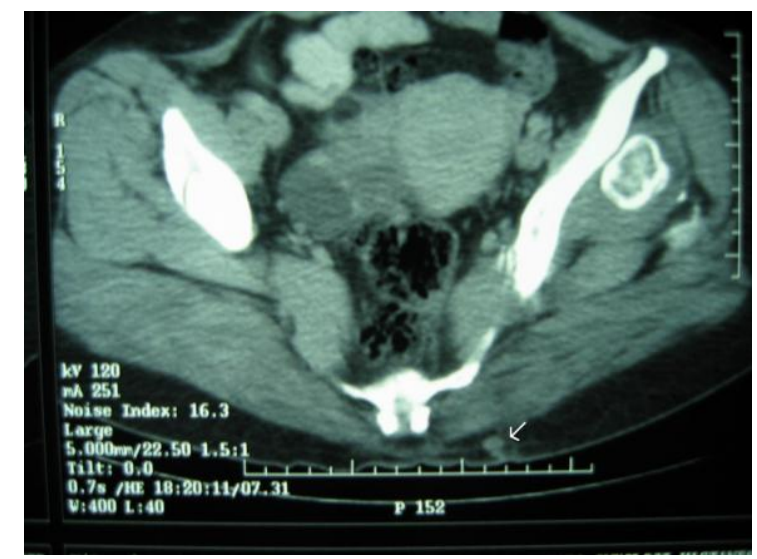

Resim 1: Bilgisayarlı tomografide sol gluteal bölge yerleşimli kemik ile ilişkisiz sınırları net olmayan kitle

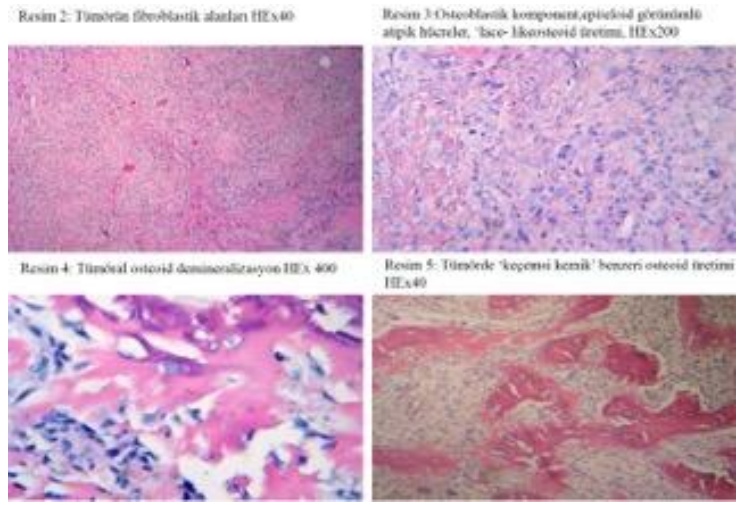

Resim 2-5; 2.Tümörün fibroblastik alanları HE, $x$ 40, 3.Osteoblastik komponent,epiteloid görünümlü atipik hücreler, 'lace-like osteoid üretimi HE,x200, 4.Tümöral osteoidde mineralizasyon HE, $\mathrm{x} 400$, 5.Tümörde 'keçemsi kemik' benzeri osteoid üretimi HE, x40

\section{Tartışma}

ESOS, yumuşak dokunun osteoid, kemik ya da kondroid materyal üreten malign mezenkimal neoplazmı olarak tanımlanır. Cerrahi sırasında gözle ya da radyografik incelemede kemik ile ilişkisi görülmeyen, yumuşak dokuda lokalize tümörlerdir. ESOS, tüm yumuşak doku sarkomlarının \%1.2'sini, osteosarkomların ise \%4'ünden azını oluşturur (1-3). ESOS, osseöz osteosarkoma kıyasla daha yaşlı hastalarda görülür (ortalama tanı yaş1 55). Kas içi ya da yüzeyel lokalizasyonda, en sık görüldüğü yer uyluk bölgesidir; bunu gluteal bölge, üst ekstremite ve retroperiton takip eder. Meme, deri, mesane, akciğer, mediasten, dil, penis, spermatik kord, cerebrum ve kolon ESOS'un bildirilmiş olağandıșı diğer lokalizasyonlanıdır (3-13). Spesifik bir bulgusu yoktur. Tümörler genellikle, giderek büyüyen yumuşak doku kitlesi ile başvurur. Olguların üçte birinde ağrı yakınması da vardır. Semptomların süresi birkaç hafta-yıl arasında değişkenlik göstermesine rağmen, sunulan olguda olduğu gibi, çoğu lezyon semptomların başlamasını izleyen 6-8 ay içinde ortaya çıkar (1). ESOS, çoğu osseöz osteosarkoma benzer şekilde yüksek dereceli histolojiye sahiptir; düşük dereceli ESOS oldukça nadirdir. Olgumuz bildirildiği üzere yüksek dereceli histomorfolojik özellikler göstermektedir. Literatürde sadece 6 olgu şeklinde düşük dereceli ESOS olgusu bildirilmiştir.

ESOS agresif bir neoplazmdir ve hastalar başlangıç tanısından sonraki 2-3 yıl içinde metastatik hastalı nedeniyle kaybedilirler (13). Ne yazık ki olguya ait klinik 
takip bilgisine ulaşılamadı. Bone ve ark.'nın 26 ESOS olgusu içeren bir çalışmasında, tümör boyutunun, temel prognostik faktör olduğu belirtilmiştir. Ancak Lee ve ark.'nın bir çalışması ile Jensen ve ark.'nın 25 olguluk çalışmasında, 5 cm'nin altındaki tümör boyutunun iyi prognoz göstergesi olduğu gösterilememiştir (2). Literatürde, ESOS'un gelişiminde birkaç predispozan faktör tanımlanmıştır. Radyasyon, intramüsküler enjeksiyon, travma ve tanısal amaçlı olarak kullanilan radyoaktif thorium dioxide suçlanmaktadır (15). Travma öyküsü, hastaların \%12.5-23'ünde bildirilmiştir. Hastamız sol doğumsal kalça çıkıklı olup, bu bulgu kronik travma lehine yorumlanabilir. Myositis ossifikans zemininde gelişen ESOS nadirdir. Diğer tümörler nedeniyle radyasyon alan hastalarda gelişen çok sayıda osseöz ve ekstraosseöz osteosarkom literatürde bildirilmiştir. ESOS'un çoğu meme karsinomu, uterin ve overkarsinomu, seminom, Wilms tümörü, Hodgkin hastalığı, nöroblastom, astrositom ya da retinoblastom gibi malign neoplazmlar nedeniyle radyoterapi alan hastalarda gelişebildiği bildirilmiştir (1). Jensen ve ark.'nın 25 olguluk çalışmasında da, 20 ve 22 yıl önce radyoterapi alan yüzeyel yerleşimli (intradermal ve subkutanöz) osteoblastik tümörü olan 2 hasta vardı.

ESOS, mikroskopik olarak osseöz osteosarkomda tanımlananlara benzer özellikte, fibroblastik, osteoblastik, kondroblastik ve telenjiektatik subtiplerine ayrilır. ESOS histolojik subtiplerinin klinik seyir ile ilşkili olduğunu gösteren farklı sonuçlar bildirilmiştir. Chung ve Enzinger, fibroblastik tip ESOS vakalarının, osteoblastik, kondroblastik ya da telenjiektazik tiplerinden biraz daha iyi prognoza sahip olduğunu göstermişlerdir. Lee ve ark. kondroblastik subtipindeki olguların, osteoblastik tipten daha iyi prognozlu olduğunu göstermişlerdir. Bone ve ark. ise, bir çalışmalarında klinik sonuç ile histolojik paternin korele olmadığını belirtmişlerdir. Yüzeyel büyümeye karş1 intramüsküler büyüme paterni gibi diğer patolojik özellikler, p53 pozitifliği gibi İHK bulgular klinik seyri anlamlı bir şekilde etkilemez. Bununla birlikte, Ki67 proliferatif indeks değerleri \%24'den çok veya daha az görülen hastaların hastalıksız sağkalımında anlamlı fark görülmüştür (2). Sunulan olguda Ki67 proliferatif indeks yaklaşık \%30 olarak saptanmıştır, bu durumun hastalıksız sağkalımı olumsuz yönde etkileyebileceği sonucuna varılabilir.

ESOS'un İHK olarak karakteristik bir özelliği yoktur. Diğer birçok mezenkimal tümörler gibi vimentin ile boyanırlar. Bazı olgularda, desmin, aktin, S-100 protein, EMA ve pansitokeratin ile fokal boyanmalar bildirilmiştir. Ayrıca, osteokalsin ve osteonektin antikorlarının, osseözve ESOS tanısında yararlı olduğu bildirilmiştir $(1,2)$. Fanburg-Smith ve ark., ESOS'un neoplastik hücrelerinin $\% 82$ 'sinin osteokalsin antikorlarına sensitif olduğu; bunun \%91'inde kemikten uzak neoplastik hücrelerde, $\% 75$ 'inde ise kemiksi tümör matriksinde boyanma olduğunu bulmuşlardır. $\mathrm{Bu}$ çalışmalarında, osteoblastların \%100'ünün osteokalsin antikorlarına karşı spesifik olduğunu belirtmişlerdir, diğer hücreler ise nonreaktiftir. Bununla birlikte osteonektin antikorları, osteoblastlar için spesifik değildir (16). Jensen ve ark.'nın yaptı̆̆ 1 çalışmada, eğer taze tümör dokusu mevcutsa, imprint yaymalarda ya da kriyostat kesitlerde alkalen fosfataz boyanmasının yardımcı olduğunu vurgulamışlardır. Bu çalışmada değerlendirilen tüm vakalarda alkalen fosfatazın güçlü pozitif reaksiyonu kuvvetle osteosarkomu düşündürmüş̧ür. $\mathrm{Bu}$ enzimin, pleomorfik sarkomlarda kullanıldığında çok yüksek ayırt ettirici özelliğe sahip olduğunu vurgulamışlardır (2).

Myositis ossifikans, ossifiye lipom, yumuşak dokunun osteomu ve ossifiye fibromiksoid tümörler, iyi diferansiye ESOS'tan ayırt edilmesi gereken benign durumlardır. Myositis ossifikans, tipik olarak zonal fenomen gösterir (kemik lamelleri periferdedir, lezyon merkezine doğru gittikçe dansite azalır). İyi diferansiye ESOS ise ters zonal fenomen görülür (tümör merkezinde kemik lamelleri veya osteoid, periferde ise atipik iğsi hücreler). Ossifiye lipom, çok büyük boyutlara ulaşabilir; fakat lipomatöz doku ve metaplastik kemik formasyonunun birlikte varlığı ile iyi diferansiye ESOS'dan ayrılır. Yumuşak dokuların osteomunda, periferde lokalize, arada yağlı ya da hematopoietik kemik iliği ile birlikte bulunan matür kemik lamellerinden oluşur. Ossifiye fibromiksoid tümörler, iyi diferansiye ESOS gibi, eski bir öykü ve yumuşak dokuda irregüler kalsifikasyon şeklinde ortaya çıabilir. Histolojisinde ise, periferde kesintili reaktif 
kemik oluşumu ve epiteloid hücre yuvaları görülür $(1,13)$.

\section{Kaynaklar}

1. Weiss SW, Goldblum JR. Enzinger and Weiss's Soft Tissue Tumors,fourth edition p:1389-14017

2. Lidang Jensen M, Schumacher B, Myhre Jensen O, Sten Nielsen O, Keler J. Extraskeletal Osteosarcomas: A clinicopathologic study of 25 cases. Am J Surg Pathol 1998;22:588-94

3. Silver SA, Tavassoli FA. Primer osteogenic sarcoma of thebreast: A clinicopathologic analysis of 50 cases. Am J Surg Pathol 1998;22:923-33

4. Santos-Juanes J, Galache C, Miralles M, Curto JR, Sanchez del Rio J, Soto J. Primarycutaneous ESOS under a previous electrod essicated actinickeratosis. J AmAcadDematol 2004;51:5166-8

5. Olgyai G, Horvath V, Kocsis J, Buza N, Olah A. ESOS in gallbladder. Magy Seb. 2003;56:57-60

6. Chapman AD, Pritchard SC, Yap WW, et al. Primary pulmonary osteosarcoma: casereport and molecular analysis. Cancer 2001;91:779-84

7. Ulusakarya A, Terrier P, Regnard JF, de Montpreville V, Munck JN. ESOS of the mediastinum after treatment of a mediastinal germ cell tumor. Am J Clin Oncol. 1999;22:609-14

8. Loyzaga JM, Fernandez Machin P, Sala J. Osteogenic sarcoma of thetongue. Case report and review of the literature. Pathol Res Pract. 1996;192:75-8

9. Bacetic D, Knezevic M, Stojsic Z, Atanackovic M, Vujanic GM. Primary ESOS of the penis with a malignant fibrous histiocytoma-like component. Histopathology 1998;33:185-6
Çıkar Çatışması: Yoktur

10. Cannon TC, Bane BL, Kistler D, et al. Primary intracerebellar osteosarcoma arising within an epidermoid cyst. Arch Pathol Lab Med 1998;122:737-9

11. Beiswanger JC, Woodruff RD, Savage PD, Assimos DG,. Primary osteosarcoma of the spermatic cord with synchronous bilateral renal cell carcinoma. Urology 1997:49:957-9

12. Shimazu K, Funata N, Yamamoto Y, Mori T. Primary osteosarcoma arising in the colon: report of case. Dis Colon Rectum. 2001;44:1367-70

13. Abramovici LC, Hytiroglou P, Klein RM, et al. Well-differantiated ESOS: report of 2 cases, 1 with dedifferentiation. Human Pathology 2005;36:439-43

14. Fang Z, Matsumoto S, Keisuke AE, et al. Post radiation soft tissue sarcoma: multi institutional analysis of 14 cases in Japan. J Orthop Sci 2004;9:242-6

15. Okada K, Ito H, Miyakoshi N, Sageshima M, Nishida J, Itoi E. A low grade extraskeletal osteosarcoma. Skeletal Radiol 2003;32;165-9

16. Fanburg-Smith JC, Bratthauer GL, Miettinen M. Osteocalcin and Osteonectin immunoreactivity in ESOS: A study of 28 cases. Human Pathology 1999;30:32-8 